\title{
Differential Bioaccumulation of Heavy Metals in Tissues of Tilapia Zilli Exposed To Liquid Habitat from River Challawa in Kano, Nigeria
}

\author{
Dr. Inalegwu B. ${ }^{1}$, Akyengo $\mathrm{O}^{1,2^{*}}$, Dr. Ogo O.A ${ }^{1,3}$, Jato J.A ${ }^{1}$
}

${ }^{1}$ Department of Biochemistry, College of Science, Federal University of Agriculture, Makurdi, P.M.B 2373, 970001, Benue State

${ }^{2}$ Effluent Monitoring and Pollution Control Centre, Nigerian Institute of Leather and Science Technology, Zawaciki, P.M.B 3329 Kano State

${ }^{3}$ Department of Biochemistry, College of Health Science, Benue State University, Km 1, Gboko Road Makurdi, P.M.B 102119; 970001 Makurdi, Benue State

DOI: $10.36348 /$ sijb.2020.v03i12.001 $\quad$ | Received: 06.07.2020 | Accepted: 13.07.2020 | Published: 05.12.2020

*Corresponding author: Akyengo $\mathrm{O}$

Email: ovey2valour@gmail.com

\section{Abstract}

Increased water body contamination by heavy metals (HMs) is a serious health hazard to both aquatic biota and their predators. The degree of contamination is a function of bioavailability and bioaffinity to an organism. Metallothioneins (MTs) - a protein with high metal binding ability was used to assess the differential bioaccumulation of HMs in liver and skeletal muscles of Tilapia Zilli. HM concentration in all the liquid habitats was above the permissible limits of Federal Ministry of Environment with Zinc having the highest concentration ranging from 6.791-11.825 ppm. Exposure of $T$. Zilli to the three liquid habitats for 72 hours with sample collection twenty-four (24) hourly showed significant $(\mathrm{P} \geq 0.05)$ induction of MTs by HMs accumulated in liver and skeletal muscle tissues of $T$. Zilli exposed to test habitats. Fishes showed higher induction in the downstream liquid habitat, where accumulation of HMs was higher in liver than muscle tissues. Fishes exposed to that habitat recorded MT concentrations of $102.859 \mu \mathrm{g} / \mathrm{g} \mathrm{WWt}$ and $83.947 \mu \mathrm{g} / \mathrm{g}$ WWt after 72 hours of exposure for liver and skeletal muscle respectively. The liver demonstrated higher bioaccumulation potential than muscle tissues and the highest bioaccumulation factor for most of the HM was associated with the downstream habitat. T. Zilli from this study bioaccumulated HM and MTs played a vital role bioaccumulation assessment of HM. Though HM in skeletal muscles were relatively low, it still poses health threat through bioaccumulation. Thus, consumption of fish from polluted bodies needs to be avoided.

Keywords: Metallothioneins, bioaccumulation, aquatic habitats, heavy metals, bioavailability.

Copyright (9) 2020 The Author(s): This is an open-access article distributed under the terms of the Creative Commons Attribution 4.0 International License (CC BY-NC 4.0) which permits unrestricted use, distribution, and reproduction in any medium for non-commercial use provided the original author and source are credited.

\section{INTRODUCTION}

Increased level of industrialization has led to an increase in the extraction and distribution of mineral substances from their natural deposit [1]. Unlike other pollutants heavy metals are non-degradable and therefore have tendency to bioaccumulate and biomagnify from one trophic level to another [2]. Heavy metals are generally referred to as those metals which possess a specific density of more than $5 \mathrm{~g} / \mathrm{cm}^{3}$ and adversely affect the environment and living organisms [3]. Bioaccumulation refers to an increase in the level of a chemical/toxicant in biological organism overtime, especially when compared to the level of the chemical/toxicant level in the environment [4]. Bioaccumulation occurs when an organism absorbs a potential toxic substance at a rate faster than that at which the substance is lost by catabolism or excretion. Thus, the longer the biological half-life of a toxic substance the greater the risk of chronic poisoning, even if environmental levels of the toxin are not very high [5]. Heavy metals are significant environmental pollutants and their toxicity is a problem of increasing significance for ecological, evolutionary, nutritional and environmental reasons [6, 7]. The most commonly found heavy metals in waste water include Arsenic, Cadmium, Chromium, Copper, Lead, Nickel, and Zinc, all of which cause risks to human health and the environment [8].

Heavy metal accumulation in the aquatic environment could result in toxicity to both aquatic life and human. Edible fish present in aquatic habitat form an important group of organism in that, metal once accumulated in fish tissues could act as a potential carrier of metal ion along the food chain. At the end, directly or indirectly the metal ion in the aquatic medium reach man and have the potential to introduce 
levels of toxicity detrimental to man's health [9]. The extent to which the fish binds and accumulate heavy metals can be a bio indicator of the extent of potential toxicity arising from ingestion of the fish [10]. Fish from polluted water pose to human health. Humans consume mostly the muscle of fish and the liver gives a representative level of contamination of the organism due to the fact that it is the main organ of detoxification. There is evidence that depending on duration and level of exposure, Degree of contamination varies between tissues [11]. Different tissues are contaminated at different levels, the degree of contamination is determined by the biochemical process of heavy metal binding to tissue [12]. Liver accumulates high concentration of metals irrespective of route of uptake, the liver is considered a good monitor of water pollution with metals concentration accumulating in this organ often proportional to that present in the environment [10]. Metal accumulation in the liver and its concentration represent storage and substantially contribute to the overall metal load in the fish [13]. Metal accumulation in the muscle is relatively low when compared with other organs, but it constitutes a greater potential risk for predatory fishes, birds and mammals feeding on contaminated fish [10].

The availability of metals in cell is thought to be regulated by the action of DNA binding metal sensors that control the expression of genes encoding metal buffering proteins such as Metallothioneins. These sensors act to maintain a buffered metal concentration within limit determined in part by metal concentration and their affinities [14]. Metallothioneins are ubiquitous low molecular weight proteins which are cysteine rich and have metal binding ability [15]. Metallothioneins are single chain polypeptide containing 61-68 amino acid with18-23 cysteine residue , with a molecular weight of 6-7 KDa (about 7000Da), Metallothioneins bind metals through its thiol (-SH) group of the cysteine residue. Typically, Metallothioneins has high affinities for multivalent metals which give rise to metal-thiolate cluster that gives high stability [16]. The accumulation of metal in fish in sub lethal exposure is time dependent. Usually, in the initial period of exposure metal is absorbed and accumulated at a high rate, and then the level stabilizes when equilibrium of metal uptake and excretion rate is attained. Metal distribution in various organs is also time-related [17].

Contamination of freshwater bodies with a wide variety of pollutant especially heavy metals has been a matter of great concern over the last decades, not only because of threat to public water supply, but also the damage to aquatic life and their ecosystem. Edible fish present in freshwater bodies form an important group of organism as heavy metals once accumulated in their tissues could act as a potential carriers of metal ion along the food chain, the extent to which fish binds and accumulate heavy metals can be a bio indicator of the extent of potential toxicity arising from consumption of these heavy metals laden fishes. These work is aimed at assessing the differential bioaccumulation of heavy metals $(\mathrm{Pb}, \mathrm{Cr}, \mathrm{Cd}, \mathrm{Zn}, \mathrm{Cu}, \mathrm{Al}$, and $\mathrm{Fe})$ using metallothioneins in liver and skeletal muscle of Tilapia zillii exposed to liquid habitats of River Challawa, Kano State.

\section{METHODOLOGY Study Area}

Challawa River is located in Challawa industrial estate in Kumbotso local government area of Kano State. Kano state is located in an area extending from latitude $12^{\circ} 40^{\prime}$ and $10^{\circ} 30^{\prime}$ and longitude $7^{\circ} 40^{\prime}$ and $9^{\circ} 40^{\prime}$ in the northern part of Nigeria. Challawa River is one of the receiving rivers of effluents from tanneries and textile to foods and packaging industries located in Challawa industrial estate, the effluent from the industries are connected by canal and channeled directly into river Challawa.

\section{Collection and identification of fish}

90 fishes (Tilapia zillii) were obtained from Tigga dam in Kano, weighing 60-100 g, the fish would be divided into three groups namely; station 1(30 fishes), station 2(30 fishes) and control (30 fishes). Station 1 is located upstream of River Challawa and is relatively less polluted while station 2 is located downstream of the same river and is highly polluted due to influx of effluent from the tannery. Fishes from the two groups were placed in polyvinyl chloride (PVC) tank containing liquid habitat obtain from the respective stations, and were fed with commercial feed. The control group was treated to liquid habitat from where the fish were obtained (Tigga dam) and also fed with commercial feed (fish meal: protein content $57.7 \%$, fat $1.8 \%$ conversion ratio $2: 1$ ) for the same period and were kept in a polyvinyl chloride (PVC) tank. Before the introduction of the liquid habitat from station one and two, Tilapia zillii was allowed to acclimatize for 45 hours and were administered anti-stressant; this was closely followed by gradual calibration of their natural habitat and the liquid habitat in which they were exposed to. This exposure lasted for three (3) days and samples from each group were collected 24 (twentyfour) hourly.

\section{Sample collection and Preparation}

The samples of each liquid habitat were collected for $\mathrm{HM}(\mathrm{Pb}, \mathrm{Cr}, \mathrm{Cd}, \mathrm{Al}, \mathrm{Zn}, \mathrm{Cu}$ and $\mathrm{Fe})$ concentration of the liquid habitat as determined by AAS. After exposure period, fishes from different groups were collected with the aid of a gill net. Obtained fishes were dissected for tissue collection namely: the liver and muscle. The muscle tissue was collected from the left side of the fish, above the lateral line and between the dorsal fin and the caudal fin; this is to prevent contamination by the content of the abdominal cavity [18]. The livers from each fish were subsequently obtained with clean equipment and a new 
latex glove was use for each fish. Samples of each liquid habitat of the experimental animals and their control were collected and analyzed.

The fish samples organs (liver and muscle) were collected fresh and then dried separately for 24 hours to constant weight in an oven at $105^{\circ} \mathrm{C}$. An aqua regia wet method of acid digestion as described by Ang and Lee was used [19]. Briefly, to $1 \mathrm{~g}$ of ground samples, $18 \mathrm{ml}$ of a fresh mixture of hydrochloric acid and nitric acid in the ratio of 3:2 was added, the mixture was boiled over a water bath $\left(95{ }^{0} \mathrm{C}\right)$ After complete digestion, the residue was made up to $50 \mathrm{ml}$ with distilled water. Digested samples were stored in precleaned polyethylene bottles until analysis using atomic absorption spectrophotometer.

\section{Quantification of metallothioneins (MT)}

Metallothionein (MT) was determined according to the methods of [20]. 0.25 g Sampled fresh tissues was weigh and placed in a homogenizing tube kept on ice, then gently homogenized in 3:1 (v/w) $10 \mathrm{mM}$ Tris- $\mathrm{HCl} \quad(\mathrm{pH}=7.4)$ buffer with a glass homogenizer and Teflon pestle. The homogenization buffer also contained $0.1 \mathrm{mM}$ phenylethylsulphonyl fluoride and $5 \mathrm{mM} \beta$-mercaptoethanol. The homogenate was centrifuged at $16000 \mathrm{~g}$ for 30 minutes at $4{ }^{\circ} \mathrm{C}$, and the supernatant was heated for 2 minutes in a boiling water bath $\left(100{ }^{0} \mathrm{C}\right)$. The heated sample was centrifuged at $10000 \mathrm{~g}$ for 10 minutes to remove precipitated proteins. Volumes of $0.1 \mathrm{ml}(500 \mu \mathrm{g} / \mathrm{L})$ of $\mathrm{CdCl}_{2}$ was mixed with $0.5 \mathrm{ml}$ of sample for 10 minutes to saturate the metal binding sites of MT.0.5 ml of $2 \%(\mathrm{w} / \mathrm{v})$ bovine hemoglobin was then added and incubated at room temperature for 10 minutes. The hemoglobin was denatured in a water bath $\left(100{ }^{\circ} \mathrm{C}\right)$ for 2 minutes, cooled in ice for 3 minutes and centrifuged at $10000 \mathrm{~g}$ for 15 minutes. The denatured protein, except for MT which is heat stable, was removed by centrifugation. Steps from the addition of the bovine hemoglobin until centrifugation were repeated three times. The amount of $\mathrm{Cd}$ ions in the final supernatant was proportional to the amount of MT present.

The concentration of $\mathrm{Cd}$ in the supernatant was determined using an atomic absorption spectrophotometer. The MT concentration was calculated by the equation given below (eqn 1):

$$
M T \text { Conc. }(\mu g / g \text { wet weight })=\frac{\text { Cd Conc. }(\mu g / g \text { wet weight })}{\frac{112.4}{7} \times 6000}---- \text { eqn } 1
$$

1 mol fish MT bound to 7 mol metal ions, assuming that the fish MT average molecular weight was assumed to be $6000 \mathrm{Da}$. The MT concentrations were calculated on the basis of a molar ratio of $\mathrm{Cd} / \mathrm{MT}$ of 7 [21].

\section{Bioaccumulation factor $(B A F)$}

Bioaccumulation factor (eqn 2) is one of the methods of assessing bioaccumulation in an organism and is important for evaluating the risk a chemical poses to humans and the environment [22].

$$
B A F=\frac{\text { concentration of chemical in organism or tissue }}{\text { concentration of chemical in the environment }}----(\text { eqn } 2)
$$

Source: [10]

\section{STATISTICAL ANALYSIS}

Results of cadmium concentration and subsequent MT quantification were reported as mean \pm standard deviation (Mean $\pm \mathrm{SD}$ ), Data were analyzed using one way analysis of variance (ANOVA) followed by Dunnett's test. Values were considered statistically significant at $\mathrm{P} \geq 0.05$. Correlation was carried out between MTs values and cadmium concentration ions to rule out the effect of other oxidative stressors.

\section{RESULTS}

After exposure of Tilapia zillii the different liquid habitat for 72 hours, heavy metals analysis was carried out for body tissues (liver and skeletal muscle tissues) and liquid habitats to obtain the bioaccumulation factor for liver tissues and skeletal muscle tissues (figure 1).

The results of heavy metals concentration in the three liquid habitats as presented in table 1 shows that zinc had the highest concentration with concentration of $6.189 \mathrm{ppm}, 6.791 \mathrm{ppm}$ and the highest of $11.588 \mathrm{ppm}$ for the control, upstream and downstream, while iron had concentration ranging from 5.380 to $6.872 \mathrm{ppm}$, copper had concentration which ranged from $1.204 \mathrm{ppm}$ to $8.198 \mathrm{ppm}$, lead had the least concentration which ranged from 0.781 to $1.825 \mathrm{ppm}$.

Results of heavy metals analysis in the liver and skeletal tissues of Tilapia zillii as presented in table 2 shows that iron had the highest concentration in the tissues with concentration of $5.476 \mathrm{mg} / \mathrm{kg}$ (liver), 4.678 $\mathrm{mg} / \mathrm{kg}$ (skeletal muscle) for control liquid habitat, while 4.859 (liver) 2.894 (skeletal muscles) for the liquid habitat upstream and 5.276 (liver) and 2.857 (skeletal muscles) for liquid habitats downstream, while lead had the least observed concentration with the liver having a concentration ranging from $0.043 \mathrm{mg} / \mathrm{kg}$ to 0.873 $\mathrm{mg} / \mathrm{kg}$ and skeletal muscles having a concentration that ranged between $0.064 \mathrm{mg} / \mathrm{kg}$ to $0.347 \mathrm{mg} / \mathrm{kg}$ across all the three test liquid habitats. 
Generally all the heavy metals were above the maximum permissible limit stipulated by Federal Ministry of Environment, except in few cases where the control liquid habitat had aluminum and chromium concentration below limit set. The concentration of heavy metal in the different habitat was in this order $\mathrm{Zn}$ $>\mathrm{Cu}>\mathrm{Fe}>\mathrm{Al}>\mathrm{Cd}>\mathrm{Cr}>\mathrm{Pb}$. Liver tissues of the test model generally showed higher level of bioaccumulation across all the heavy metal tested for when compared to their corresponding skeletal muscle tissues, while the tissues exposed to downstream liquid habitat generally had higher level of bioaccumulation compared to corresponding tissues exposed to other test liquid habitats.

Table-1: Mean concentration \pm standard deviation of heavy metals in the three different liquid habitats and maximum permissible limit as stipulated by federal Ministry of Environment for surface water

\begin{tabular}{|l|l|l|l|l|}
\hline Metals & Control $(\mathbf{p p m})$ & Upstream $(\mathbf{p p m})$ & Downstream $(\mathbf{p p m})$ & $\begin{array}{l}\text { MPL by Fed. Min. } \\
\text { of Env. }\end{array}$ \\
\hline Cadmium & $0.288 \pm 0.001^{\mathrm{a}}$ & $1.890 \pm 5.77^{\mathrm{b}}$ & $2.008 \pm 0.009^{\mathrm{c}}$ & 0.010 \\
\hline Chromium & $0.048 \pm 0.001^{\mathrm{a}}$ & $1.061 \pm 0.000^{\mathrm{b}}$ & $2.584 \pm 0.000^{\mathrm{c}}$ & 0.500 \\
\hline Lead & $0.781 \pm 0.001^{\mathrm{a}}$ & $1.091 \pm 0.001^{\mathrm{b}}$ & $1.825 \pm 0.001^{\mathrm{c}}$ & 0.100 \\
\hline Aluminum & $0.210 \pm 0.001^{\mathrm{a}}$ & $5.529 \pm 0.001^{\mathrm{b}}$ & $8.411 \pm 0.001^{\mathrm{c}}$ & 0.900 \\
\hline Iron & $5.380 \pm 0.001^{\mathrm{a}}$ & $5.593 \pm 0.000^{\mathrm{a}}$ & $6.872 \pm 0.001^{\mathrm{b}}$ & 0.500 \\
\hline Zinc & $6.189 \pm 0.001^{\mathrm{a}}$ & $6.791 \pm 0.001^{\mathrm{b}}$ & $11.588 \pm 0.001^{\mathrm{c}}$ & 0.200 \\
\hline Copper & $1.204 \pm 0.001^{\mathrm{a}}$ & $3.150 \pm 0.000^{\mathrm{b}}$ & $8.198 \pm 0.001^{\mathrm{c}}$ & 0.010 \\
\hline
\end{tabular}

Legend: $M P L=$ Maximum permissible limit

Table-2: Mean concentration \pm standard deviation of heavy metal $(\mathrm{mg} / \mathrm{kg})$ in liver and muscle tissues of Tilapia zillii exposed to three test liquid habitat

\begin{tabular}{|l|l|l|l|l|l|l|l|}
\hline T and H & Copper & Cadmium & Chromium & Zinc & Lead & Aluminum & Iron \\
\hline L-C & $0.655 \pm 0.00^{\mathrm{a}}$ & $0.010 \pm 0.00^{\mathrm{a}}$ & $0.002 \pm 0.00^{\mathrm{a}}$ & $4.517 \pm 0.00^{\mathrm{b}}$ & $0.043 \pm 0.00^{\mathrm{a}}$ & $0.017 \pm 0.00^{\mathrm{a}}$ & $5.476 \pm 0.00^{\mathrm{c}}$ \\
\hline SM-C & $0.224 \pm 0.00^{\mathrm{a}}$ & $0.012 \pm 0.00^{\mathrm{a}}$ & $0.024 \pm 0.00^{\mathrm{a}}$ & $0.467 \pm 0.00^{\mathrm{a}}$ & $0.064 \pm 0.00^{\mathrm{a}}$ & $0.006 \pm 0.00^{\mathrm{a}}$ & $4.678 \pm 0.00^{\mathrm{a}}$ \\
\hline L-US & $3.205 \pm 0.00^{\mathrm{c}}$ & $1.248 \pm 0.00^{\mathrm{b}}$ & $0.511 \pm 0.00^{\mathrm{a}}$ & $6.859 \pm 0.00^{\mathrm{c}}$ & $0.427 \pm 0.00^{\mathrm{a}}$ & $0.355 \pm 0.00^{\mathrm{a}}$ & $4.859 \pm 0.00^{\mathrm{a}}$ \\
\hline SM-US & $1.446 \pm 0.00^{\mathrm{b}}$ & $0.678 \pm 0.00^{\mathrm{a}}$ & $0.231 \pm 0.00^{\mathrm{a}}$ & $5.205 \pm 0.00^{\mathrm{b}}$ & $0.146 \pm 0.00^{\mathrm{a}}$ & $0.198 \pm 0.00^{\mathrm{a}}$ & $2.894 \pm 0.00^{\mathrm{a}}$ \\
\hline L-DS & $8.683 \pm 0.00^{\mathrm{d}}$ & $2.248 \pm 0.00^{\mathrm{b}}$ & $2.648 \pm 0.00^{\mathrm{b}}$ & $11.488 \pm 0.00^{\mathrm{d}}$ & $0.873 \pm 0.00^{\mathrm{a}}$ & $6.416 \pm 0.00^{\mathrm{b}}$ & $5.276 \pm 0.00^{\mathrm{c}}$ \\
\hline SM-DS & $4.164 \pm 0.00^{\mathrm{c}}$ & $0.644 \pm 0.0^{\mathrm{c}}$ & $0.848 \pm 0.00^{\mathrm{a}}$ & $5.429 \pm 0.00^{\mathrm{b}}$ & $0.347 \pm 0.00^{\mathrm{a}}$ & $3.211 \pm 0.00^{\mathrm{b}}$ & $2.857 \pm 0.00^{\mathrm{a}}$ \\
\hline
\end{tabular}

Legend: $\mathrm{T}$ and $\mathrm{H}=$ Tissue and Habitat; L-C = Liver control; SM-C = skeletal Muscle Control; L-US = Liver Upstream;

SM-US = Skeletal Muscle Upstream; L-DS = Liver Downstream; SM-DS = Skeletal Muscle Downstream

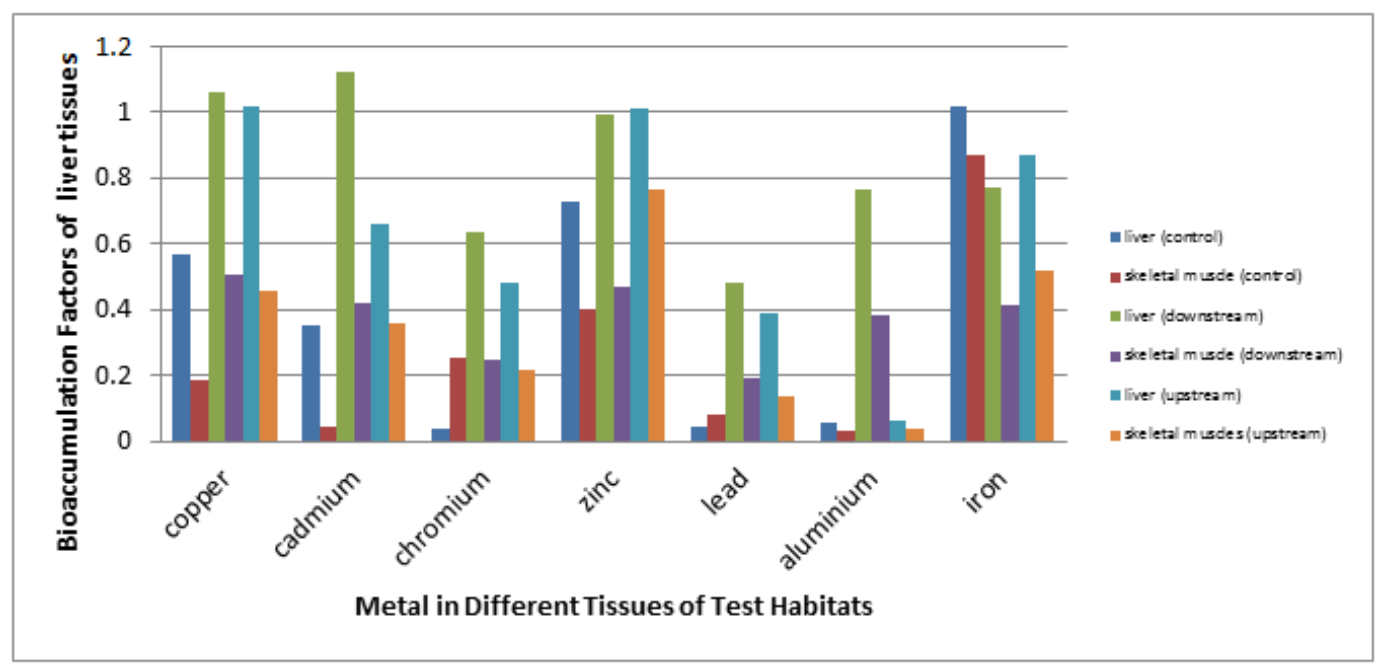

Fig-1: Bioaccumulation factor for liver and skeletal muscles tissues of Tilapia zillii exposed to the test liquid habitats for a duration of 72 hours.

MT was quantified after exposure of 72 hours at intervals of 24 hours to the different liquid habitats, after addition of cadmium the MT was quantified and results presented in table 3 and 4 . From the results the liver tissue of Tilapia zillii induced more MT than the skeletal muscle tissue across all the liquid habitats which the test model was exposed to, results of cadmium concentration which was used to bind to all other sites previously occupied by other heavy metals measured presented in table 3. shows higher concentration for Tilapia zillii tissues exposed to the liquid habitat downstream with concentration ranging from $6.185 \mu \mathrm{g} / \mathrm{g}$ wwt to $11.528 \mu \mathrm{g} / \mathrm{g}$ wwt for liver tissues and $2.168 \mu \mathrm{g} / \mathrm{g}$ wwt to $9.436 \mu \mathrm{g} / \mathrm{g}$ wwt for skeletal muscle tissue compared with lower concentration obtained for the control with values ranging from $1.462 \mu \mathrm{g} / \mathrm{g}$ wwt to $2.732 \mu \mathrm{g} / \mathrm{g}$ wwt for liver tissues and 0.561 to $1.914 \mu \mathrm{g} / \mathrm{g}$ wwt for skeletal 
muscle tissues. This pattern was maintained in result of MT quantification as presented in table 4 with the test sample exposed to the liquid habitats having higher concentration of 60.631 to $104.511 \mu \mathrm{g} / \mathrm{g}$ wwt for liver tissues and 19.291 to $89.570 \mu \mathrm{g} / \mathrm{g}$ wwt for skeletal muscle. Liver tissues had higher values for both cadmium concentration and subsequent MT concentration compared to their corresponding skeletal muscle concentration of measured cadmium and quantified MTs. There was positive correlation between the concentration of cadmium measured and corresponding concentration of MT both tissues of liver and skeletal muscles of Tilapia zillii using Pearson's correlation coefficient with $\mathrm{p} \geq 0.05$, while there was significant differences between the start concentration (control) of cadmium and metallothionein with other varied period of exposure at $\mathrm{p} \geq 0.05$ using Dunnett's student t-test.

Table-3: Mean \pm Concentration of Cadmium in Liver and Skeletal Muscles Tissues of Tilapia zillii after Exposure for 72 Hours to Different Liquid Habitats

\begin{tabular}{|c|c|c|c|c|}
\hline Tissue and Habitat & $\begin{array}{l}\text { START } \\
\mu \mathrm{g} / \mathrm{g} w \mathrm{w}\end{array}$ & $\begin{array}{l}\text { After } 24 \text { hr } \\
\mu \mathrm{g} / \mathrm{g} \text { wwt }\end{array}$ & $\begin{array}{l}\text { After } 48 \text { hr } \\
\mu \mathrm{g} / \mathrm{g} w w t\end{array}$ & $\begin{array}{l}\text { After } 72 \text { hr } \\
\mu \mathrm{g} / \mathrm{g} \text { wwt }\end{array}$ \\
\hline $\mathrm{L}-\mathrm{C}$ & $0.304 \pm 0.009^{* b}$ & $2.667 \pm 0.101^{* b}$ & $2.794 \pm 0.0998^{* b}$ & $2.732 \pm 0.071^{* b}$ \\
\hline SM-C & $0.104 \pm 0.004^{* a}$ & $1.107 \pm 0.003^{* a}$ & $2.142 \pm 0.029^{* a}$ & $1.914 \pm 0.082^{* a}$ \\
\hline L-US & $0.304 \pm 0.009^{* \mathrm{~b}}$ & $8.663 \pm 0.287^{* \mathrm{e}}$ & $9.467 \pm 0.13^{* \mathrm{~d}}$ & $9.576 \pm 0.119^{* d}$ \\
\hline SM-US & $0.104 \pm 0.009^{* a}$ & $4.659 \pm 0.148^{* \mathrm{c}}$ & $7.839 \pm 0.057^{* \mathrm{c}}$ & $7.194 \pm 0.07^{5 * \mathrm{c}}$ \\
\hline L-DS & $0.304 \pm 0.009^{* b}$ & $10.563 \pm 0.086^{* \mathrm{f}}$ & $10.501 \pm 0.008^{* \mathrm{e}}$ & $11.528 \pm 0.041^{* \mathrm{e}}$ \\
\hline SM-DS & $0.104 \pm 0.004^{* \mathrm{a}}$ & $5.579 \pm 0.075^{* d}$ & $9.301 \pm 0.014^{* d}$ & $9.436 \pm 0.027^{* \mathrm{~d}}$ \\
\hline
\end{tabular}

- $\quad$ Legend: L-C = Liver control; $\mathrm{SM-C}$ = skeletal Muscle Control; L-US = Liver Upstream; SM-US = Skeletal Muscle Upstream; L-DS = Liver Downstream; SM-DS $=$ Skeletal Muscle Downstream

- Results are presented as mean \pm standard deviations, * shows significance at $\mathrm{p} \geq 0.05$ using Dunnett's student t-test which compares control (start) with other varied period of exposure for liver and skeletal muscles of Tilapia zillii in all the liquid habitats they were exposed to.

- While a shows correlation at $\mathrm{P} \geq 0.05$ using Pearson correlation coefficient which compared concentration of cadmium obtained after induction with corresponding metallothioneins concentration.

- wwt- wet weight

Table-4: Mean \pm Concentration of Metallothioneins in Liver and Skeletal Muscle Tissues of Tilapia Zillii after Exposure for 72 Hours to Different Liquid Habitats

\begin{tabular}{|c|c|c|c|c|}
\hline Tissue and Habitat & $\begin{array}{l}\text { Start } \\
\mu \mathrm{g} / \mathrm{g} \text { wwt }\end{array}$ & $\begin{array}{l}\text { After } 24 \mathrm{Hr} \\
\mu \mathrm{g} / \mathrm{g} \text { wwt }\end{array}$ & $\begin{array}{l}\text { After 48hr } \\
\mu \mathrm{g} / \mathrm{g} \text { wwt }\end{array}$ & $\begin{array}{l}\text { After } 72 \mathrm{Hr} \\
\mu \mathrm{g} / \mathrm{g} \text { wwt }\end{array}$ \\
\hline $\mathrm{L}-\mathrm{C}$ & $2.706 \pm 0.001^{* b}$ & $23.725 \pm 0.071^{* b}$ & $24.864 \pm 0.005^{* b}$ & $24.309 \pm 0.006^{* b}$ \\
\hline SM-C & $0.921 \pm 0.011^{* a}$ & $9.848 \pm 0.021^{* \mathrm{a}}$ & $19.054 \pm 0.033^{* a}$ & $17.031 \pm 0.003^{* a}$ \\
\hline L-US & $2.706 \pm 0.001^{* b}$ & $77.076 \pm 1.389^{* \mathrm{c}}$ & $84.223 \pm 0.428^{* d}$ & $85.193 \pm 0.508^{* d}$ \\
\hline SM-US & $0.921 \pm 0.011^{* a}$ & $41.456 \pm 1.188^{* b}$ & $69.748 \pm 0.168^{* \mathrm{c}}$ & $64.006 \pm 0.286^{* \mathrm{c}}$ \\
\hline L-DS & $2.706 \pm 0.001^{* b}$ & $93.974 \pm 2.274^{* d}$ & $93.422 \pm 0.764^{* \mathrm{e}}$ & $102.859 \pm 1.534^{* \mathrm{e}}$ \\
\hline SM-DS & $0.921 \pm 0.011^{* a}$ & $49.638 \pm 2.243^{* b}$ & $82.746 \pm 1.349^{* d}$ & $83.947 \pm 0.774^{* \mathrm{~d}}$ \\
\hline
\end{tabular}

- $\quad$ Legend: L-C = Liver control; SM-C = skeletal Muscle Control; L-US = Liver Upstream; SM-US = Skeletal Muscle Upstream; L-DS = Liver Downstream; SM-DS $=$ Skeletal Muscle Downstream

- Results are presented as mean \pm standard deviations, $*$ shows significance at $p \geq 0.05$ using Dunnett's student t-test which compares control (start) with other varied period of exposure for liver and skeletal muscles of Tilapia zillii in all the liquid habitats they were exposed to.

- While a shows correlation at $\mathrm{P} \geq 0.05$ using Pearson correlation coefficient which compared concentration of cadmium obtained after induction with corresponding metallothioneins concentration.

- wwt- wet weight

\section{DISCUSSION}

HM analysis of the test liquid habitats show that all HM were above the Nigerian Federal Ministry of Environment fixed safe limits and are considered deleterious, unsafe and poses a threat to the survival of aquatic life, this results agrees with findings of [23].

Tilapia zillii accumulate heavy metals in their tissues after exposure to these heavy metals in the liquid habitats, zinc was the most abundant metal in the whole tissue of Tilapia zillii after exposure for 72 hours this finding is in agreement with work by [24] which studied three different fish species and found zinc to be the most abundant in all the tissues examined. 
The general trend that the liver accumulated HM higher than the skeletal muscles across the tested liquid habitats was consistent with other findings [25, $26,12,27]$. The liver being the first point of contact for HM metabolism and detoxification accounts for this trend [12].

MTs quantification showed that the liver had higher concentration when compared to concentration of skeletal muscles which is collaborated with the findings [28]. They worked with catfish MT and found that the MT concentration in the liver of catfish was higher when exposed to chemical additive effluent for 72 hours.

MT has been reported to increase with increased exposure to heavy metal mixture [29]. The Findings of this study indicate that higher bioavailability of heavy metals induced higher MT when exposed to contaminated liquid habitats as reflected by the high concentration of MT especially in the liver of Tilapia zillii exposed to the liquid habitat downstream.

Concentration of MT was found to correlate positively using Pearson correlation coefficient at $\mathrm{P} \geq$ 0.05 considered significant with concentration of cadmium in both the liver and skeletal muscle tissues of Tilapia zillii in all the test liquid habitats. This is indicative of a direct relationship between heavy metal accumulation and MT concentrations and has been opined to be tissue specific, in that most tissues are in direct interface with the environment [11]. Thus they are frequent targets of environmental pollutants, as such any adverse change in the ambient environment such as oxidative stress is easily reflected in these tissues, and examples of such tissues are gills and mantles of fishes. Using Dunnett's student t-test to compare, and the start concentration as control and other periods of exposure, there was significant $(\mathrm{p} \geq 0.05)$ increase between the start concentration of MTs and that of subsequent periods of exposure.

The relationship between heavy metal accumulation and MT concentration is also time dependent as metal concentration changes during and after exposure, the effect of metal accumulation with time is a complex issue due the different affinity of various metals to the tissues of fishes [10].

Bioaccumulation factor calculated for whole tissues, liver tissues and skeletal muscles tissues of tilapia zillii exposed to the three liquid habitats, of these liquid habitats, the downstream habitat had higher bioaccumulation factors with the exception of iron where the control had higher values, these pattern was also maintained in the bioaccumulation factors of heavy metals in the tissues of the liver and skeletal muscles of Tilapia zillii, this observed pattern is elucidated by the assertion by [10] that the more the concentration in the environment the more they can be taken up and accumulated in fish tissues.

The liver bioaccumulated more heavy metal than the skeletal muscles as contained in the results of the bioaccumulation factor of heavy metals for the two tissues across the three test habitats $[30,31]$ in their separate submissions had reported that muscle tissue had a weak accumulating potentials and accumulate lower level of heavy metals when compare to the liver. Conversely, the liver is considered to have a high accumulating ability due to the presence and activity of metal binding proteins such as MTs, which can bind with heavy metals and thus reducing their toxicity and allowing the liver to accumulate high concentration of these toxic heavy metals $[32,12,31]$.

\section{CONCLUSION}

Using $T$. zilli as a case study on the safety of River Challawa and the health of aquatic animals and their predators, it is concluded that there was a high level of HM in River Challawa which bioaccumulates in liver and skeletal muscles of inhabiting fishes. Bioaccumulation studies with Tilapia zillii for a period of 72 hours are achievable using laboratory conditions. Thus housed Tilapia zillii was able to induced sufficient quantity of MT to bind bioaccumulated heavy metals in its liver and skeletal muscle tissues upon exposure to the liquid habitat. This gave rise to the relationship that MT concentration increases with increased heavy metals accumulation presenting a positive correlation between heavy metals accumulation and the concentration of MT.

\section{RECOMMENDATION}

The fact that fish skeletal muscle tissue is the most consumed part still makes consumption of fish from contaminated water bodies such as Challawa River a matter of public worry even though the skeletal muscles accumulated lower levels of HM than the liver. Metallothioneins is recommended for used as a bioindicator of heavy metal accumulation for fish, this is justified by the observed relationship between MT and heavy metals, such that increased heavy metal accumulation is accompanied by an increased induction of MT. Consumption of fish from River Challawa could pose serious threat to humans and other predators of fish, despite the lower level of heavy metals in the skeletal muscles and it is recommended that consumption of fish from polluted water bodies been stopped.

It is recommended that a phytoremediation project with focus on decontamination of River Challawa be embarked upon by the Kano State and/or Federal Ministry of Environment. Also constant monitoring and control of effluent discharged to River Challawa be done to ameliorate the deteriorating nature of the river and for the good of fishes and other aquatic organisms and the end consumers of such organisms. 


\section{CONFLICT OF INTEREST}

Authors declare no conflict of interest

\section{REFERENCES}

1. Morais, S., Costa, F. G., \& Pereira, M. L. (2012). Heavy metals and human health, in Environmental health - emerging issues and practice (Oosthuizen J ed), 227-246, InTech

2. Oti, W. J. O., Nwabue, F. I., \& Afiukwa, J. N. (2012). Analysis of heavy metals in soil of Enyigba and Abakaliki. Environment and Pollution, (2), 183-193

3. Jarup, L. (2003). Hazards of Heavy Metal Contamination. Britain Medical Bulletin, 68(1), 167-182.

4. Gupta, N., Gaurav, S. S., \& Kumar, A. (2013). Molecular Basis of Aluminium Toxicity in Plants: A Review. American Journal of Plant Science, 4, 21-37.

5. Bryan, G.W., Wandrichulk, M., Rentreath, R.J., \& Dairacott, A. (2010). Bioaccumulation of Marine Pollutants, Philosophical Transaction of the Royal Society of London. B series, biological sciences, 22: $122-128$

6. Jaishankar, M., Mathew, B. B., Shah, M. S., \& Gowda, K. R. S. (2014). Biosorption of Few Heavy Metal Ions Using Agricultural Wastes. Journal of Environment Pollution and Human Health, 2(1), $1-6$

7. Nagajyoti, P. C., Lee, K. D., \& Sreekanth, T. V. M. (2010). Heavy Metals, Occurrence and Toxicity for Plants: A Review. Environment Chemistry Journal, 8(3), 199-216.

8. Lambert, M., Leven, B. A., \& Green R. M. (2000). New methods of cleaning up heavy metal in soils and water. Environmental science and technology briefs for citizens. Kansas State University, Manhattan, Kansas, 103-108

9. Davis, U., C. (2010). Case Study: Elemental Toxicity in Animals, UC Davis ChemWiki, University of California, Available at: www.google.com_(June, 2019)

10. Jizierska, B., \& Witesta, M. (2006). Metal Uptake and Accumulation in Fish Living in Polluted Water.Soil and Water Pollution Monitoring, Protection and Remediation. 3(23):107-114.

11. Li, Y., Yang, H., Liu, N., Luo, J., Wang, Q., \& Wang, L. (2015). Cadmium Accumulation and Metallothionein Biosynthesis in Cadmium-Treated Freshwater Mussel Anodonta woodiana. PLoS ONE 10(2), e0117037.

12. Ploetz, D. M., Fitts, B. E., \& Rice, T.M. (2007). Differential Accumulation of Heavy Metals in Muscles and Liver of a Marine Fish, (King Mackerel, Scomberomorus cavalla, Cuvier) from the Northern Gulf of Mexico, USA. Bulletin Environmental Contamination and Toxicology, 78, 124-127.

13. Yilmaz, A. B. (2003). Levels of Heavy Metals (Fe, $\mathrm{Cu}, \mathrm{Ni}, \mathrm{Cr}, \mathrm{Pb}$, and $\mathrm{Zn}$ ) in Tissue of Mugil cephalus and Trachurus mediterraneus from Iskenderun Bay, Turkey. Environmental Research, 92, 277-281.

14. Helmann, J. D., Soonsanga, S. \& Gabriel, S. (2007). Metalloregulators: Arbiters of Metal Sufficiency. Microbiology Monogram, 6, 37-71.

15. Sani, G., \& Carpené E. (2014). metalothionines, Unconventional proteins from Unconventional Animals: A long journey from Nematodes to mammals. Biomelecules, 4(2), 435-457

16. Santos, C. R. A., Martinho, A., Quintela, T., \& Goncalves, I. (2012). Neuroprotective and Neurogenerative Properties of metallothionines. IUBMB life, 64(2), $126-135$

17. Jezierska, B., \& Witeska, M. (2001). Metal Toxicity to Fish, Wydawnictwo Akademii Podlaskiej, Siedlce, (318), 1-7.

18. POPS toolkits: www.popstoolkit.com/sops/methods/fish.aspx.

19. Ang, H., \& Lee, K. (2005).Analysis of Mercury in Malaysian Herbal Preparation. A Peer Review. Biomedical Sciences, 4:31-36.

20. Ma, W., Wang, L., He, Y., \& Yan, Y. (2007). Tissue-specific Cadmium and Metallothionein Levels in Sinopotamon henanense.Environment Toxicolog, 23(3), 393-400.

21. Kito, H., Ose, Y., Mizuhira, V., Sato, T., \& Ishikawa, T. (1982). Separation and purification of $(\mathrm{Cd}, \mathrm{Cu}, \mathrm{Zn})$-metallothionein in carp hepatopancreas. Comparative Biochemistry and Physiology, 73, 121-127

22. Arnot, J.A., \& Gobas, F.A.P.C. (2003). A generic QSAR for Assessing the Bioaccumulation Potential of Organic Chemicals in Aquatic Food Webs. QSAR Combined Science, 22:337-345.

23. Putshaka, J.D., Akyengo, O., Yakubu, A., \& Adejube, A.A.H. (2015). Bioaccumulation of heavy metals in fish (Tilapia zillii) and Bullfrog (Pyxicephalus edulis) from River Challawa Kano State Nigeria. International Journal of Ecological and Environmental Engineering, 2(4), 30-34

24. Orata, F., \& Birgen, F. (2016). Fish Tissue BioConcentration and Interspecies Uptake of Heavy Metals from Waste Water Lagoons. Journal of pollution effect and control, 4, 157-163

25. Rashed, M.N. (2001). Monitoring of Environmental Heavy Metals in Fish from Nasser Lake. Environmental International journal, 27, 2733.

26. Dural, M., Goksu, M. Z. I., Ozak, A. A., \& Derici, B. (2006). Bioaccumulation of some Heavy Metals in Different Tissues of DicentrachuslabraxL., 1758, Sparusaurata L., 1758, and Mugilcephalus L., 1758 from the Camlik Lagoon of the Eastern Coast of Mediterranean (Turkey). Environmental.Monitoring Assesments. 118: 66-74.

27. Agah, H., Leermakers, M., Elskens, M., Fatemi, S. M. R., \& Baeyens, W. (2009). Accumulation of Trace Metals in the Muscle and Liver Tissues of Five Fish Species from the Persian Gulf. 
Environmental Monitoring Assessments, 157, 499514.

28. Mani, R., Meena, B., \& Valivittan, K. (2014). Metallothionein Induction on Exposure to Cadmium in Marine Catfish Arius arius. International Journal of Biological and Pharmaceutical Research, 5(4), 293-300.

29. Hogstrand, C., Lithner, G., \& Haux, C. (1991). The Importance of Metallothionein for the Accumulation of Copper, Zinc and Cadmium in Environmentally Exposed Perch, Perca fluviatilis .Pharmacology \& Toxicology, 68:492-501.

30. Bervoets, L., \& Blust, R. (2003). Metal concentrations in water sediment and gudgeon (Gobiogobio) from a Pollution Gradient:
Relationship with Fish Condition Factor. Environment Pollution, 126: 9-19.

31. Uysal, K., Kose, E., Bulbul, M., Donmez, M., Erdogan, Y., Koyun, M., Omeroglu, C., \& Ozmal, F. (2009). The Comparison of Heavy Metal Accumulation Ratios of some Fish Species in EnneDarne Lake (Kutahya, Turkey). Environmental Monitoring and Assessment, 157, 355-362.

32. Wu, S. M., Jong, K. J., \& Lee, Y.J. (2006). Relationship among Methallothionein, Cadmium Accumulation, and Cadmium Tolerance in Three Species of Fish. Bulletin of Environmental Contamination and Toxicology, 76, 595-600. 